\title{
Media Papan balik sebagai Sarana Meningkatkan Kemampuan Membaca Permulaan Siswa Autis
}

\author{
Ahmad Sofwan', Wiwik Dwi Hastuti², Agung Kurniawan ${ }^{3}$ \\ ${ }^{1}$ SLB Autis Lab UM \\ ${ }^{2,3}$ Universitas Negeri Malang \\ Email: Ahmadsofwanbagus12@gmail.com
}

\begin{abstract}
Abstrak: Pengaruh media papan balik Terhadap Kemampuan membaca Permulaan siswa Autis. Penelitian ini dilatarbelakangi karena kemampuan membaca permulaan siswa yang rendah. Penelitian ini bertujuan untuk mengetahui pengaruh penggunaan media papan balik dalam meningkatkan kemampuan membaca permulaan siswa autis kelas 1. Metode yang digunakan adalah eksperimen dengan subjek penelitian tunggal desain A-B-A. Hasil Penelitian yang diperoleh yaitu baseline-1 mengalami peningkatan 40,5\%$46 \%$, dan kondisi intervensi mengalami peningkatan 71,8\%-82,3\% serta di kondisi baseline- 2 mengalami peningkatan $62,8 \%-72,6 \%$. \% . Kesimpulannya media papan balik memiliki pengaruh positif terhadap kemampuan membaca permulaan siswa autis.
\end{abstract}

Kata Kunci: papan balik, kemampuan membaca permulaan, Autis

\begin{abstract}
The Effect of Backboard Media on Basic Reading Skills of Autistic students. The study is done because of reading skill the beginning of the students is low. This study aims to determine the effect of the use of backboard media in improving the reading skills of beginning on the kids autistic grade 1 . The method used is an experiment with a single research subject A-B-A design . The research results obtained were baseline- 1 which gained an increase of $40.5 \%-46 \%$, and intervention conditions increased $71.8 \%-82.3 \%$ and in baseline- 2 conditions experienced an increase of $62.8 \%-72.6 \%$. The conclusion of backboard media has a positive influence on basic reading skill of autistic student.

Keywords: Backboard media, Basic reading, Autistic
\end{abstract}

Membaca permulaan merupakan tahap membaca yang harus dilalui siswa sebagai tahapan untuk menuju tahap membaca selanjutnya. Kemampuan membaca permulaan ini sangat penting untuk ditelaah oleh semua siswa termasuk siswa berkebutuhan khusus, seperti anak autis. Hasil observasi yang didapatkan oleh penulis terhadap siswa autis yang dijadikan subjek masih mengalami kesulitan dalam membaca permulaan. Subjek penelitian sudah mengenal abjat secara baik namun dalam membaca suku kata menjadi kata masih rendah serta intonasi yang diucapkan belum jelas. Siswa penyandang autis adalah seorang anak yang mengalami hambatan dalam berkomunikasi, menjalin hubungan (social interaction) serta dalam berperilaku.

Sesuai definisi yang dikemukakan oleh Koswara (2013) Autis merupakan hambatan perkembangan pada anak yang meliputi aspek kognitif, persepsi, linguistik, serta komunikasi dari yang ringan sampai berat. Sehingga anak terlihat hidup dalam dunia sendiri dan kesulitan untuk menjalin komunikasi. Ketika pelaksanaan pembelajaran dibutuhkan sebuah perlakuan agar siswa tertarik untuk belajar. Hal tersebut dikarenakan ketidakmampuan siswa autis dalam membuat kontak mata saat berinteraksi. Sesuai dengan hal tersebut menurut Ayu dan Sudarsini (2016)
Salah satu penghambat dalam kegiatan pembelajaran pada anak autis adalah ketidakmampuan anak dalam membuat kontak mata ketika berinteraks

Kontak mata merupakan kemampuan untuk melakukan hubungan timbal balik sebagai awal terjadiya interaksi sosial melalui tatap muka atau mata secara langsung Salim (2007). Sehingga kemampuan dalam membuat kontak merupakan sesuatu yang sangat penting untuk berinterkasi. Peter dan Mastergeorge (2012) menyatakan bahwa "The systematically expressed some types of nonverbal communication with eye contact". Oleh karena itu dibutuhkan sebuah pemakaian media yang menarik agar dapat menimbulkan minat siswa dalam belajar.

Membaca adalah aspek keterampilan berbahasa awal disekolah. Pernyataan ini diungkapkan oleh Tarigan (2008) bahwa keterampilan berbahasa di sekolah meliputi keterampilan mendengarkan, berbicara, membaca, serta menulis. Sejalan dengan hal tersebut Wahyudin (2017) mengemukakan bahwa membaca merupakan suatu keahlian untuk melihat lambang-lambang tertulis melalui ucapan kemudian menuju bahasa lisan. Sehingga dapat dikatakan bahwa membaca adalah aspek berbahasa yang harus dikuasai oleh siswa sebagai prasayarat ketahap selanjutnya. Langkah awal dalam membaca adalah membaca 
permulaan di kelas rendah. Adapun tahap dasar membaca permulaan yaitu dimulai dengan mengenal huruf, suku kata sampai menjadi kata yang bermakna.

Pada tahap membaca permulaan diharapkan anak dapat mengenal abjad, suku kata, kata maupun kalimat. Kemampuan membaca permulaan merupakan dasar bagi kemampuan membaca berikutnya dan apabila dasar tersebut tidak kuat, maka akan berpengaruh pada fase membaca selanjutnya, dimana siswa akan kesulitan dalam mengoptimalkan kemampuan membacanya (Nafiah, 2016).

Dalam proses pembelajaran membaca permulaan banyak menggunakan berbagai metode ataupun media. Media digunakan untuk menyampaikan segala sesuatu sehingga menarik minat peserta didik saat belajar terhadap materi yang diberikan (Kustiawan. 2018). Media papan balik adalah salah satu media yang digunakan. Media papan balik ini merupakan modifikasi dari flipchart. Menurut Pratiwi (2013) menjelaskan bahwa media papan balik (flipchart) adalah lembaran yang dijilid menjadi satu berisi gambar, huruf, diagram maupun angka. Namun papan balik dalam penelitian ini adalah papan balik yang sudah dimodifikasi dalam bentuk papan yang terbuat dari kayu triplek tebal dan dapat dibalik berisi gambar, angka serta kartu huruf yang bisa diganti sesuai dengan tema pembelajaran.

Papan Balik berasal dari kata Papan dan Balik. Menurut Kamus Besar Bahasa Indonesia (KBBI) "Papan artinya kayu, besi dan sebagainya yang berukuran lebar dan tipis. Balik artinya sisi sebelah belakang dari yang terlihat". Sehingga media papan balik adalah media berbentuk papan yang terbuat dari kayu dan dapat dibalik untuk melihat sisi yang lain. papan balik yaitu media visual modifikasi dari lembar balik (flipchart) yang berisi gambar dan huruf atau kalimat yang terbuat dari tripleks berukuran $175 \mathrm{~cm} \mathrm{x}$ $85 \mathrm{~cm}$. Pada bagian dalam media ini terdapat papan persegi panjang pada sisi atas dan bawah dengan ukuran yang disesuaikan dan dapat dibalik. Gambar dan huruf yang terdapat dalam media papan balik adalah tentang membaca permulaan sub tema merawat tubuhku.

Media papan balik ini memudahkan siswa dalam mengenal huruf, suku kata maupun gambar yang berada di papan yang dapat dibalik. Selain memudahkan siswa media ini juga cukup menarik sehingga dapat digunakan untuk siswa dengan rentang perhatian atau konsentrasi yang rendah.

Pada umumnya siswa kelas 1 sudah dapat membaca kata sederhana sebagai langkah awal dalam membaca permulaan. Akan tetapi berdasarkan pengamatan pada siswa autis kelas 1, keterampilan dalam membaca masih rendah. Oleh karena itu penulis membuat media papan balik semenarik mungkin sebagai media dalam meningkatkan kemampuan membaca. Berdasarkan permasalahan tersebut diambil rumusan masalah sebagai berikut "pengaruh media papan balik terhadap kemampuan membaca permulaan siswa autis kelas 1".

\section{METODE}

Metode yang digunakan adalah eksperimen. Metode ini digunakan untuk mengetahui pengaruh pemberian suatu perlakuan (treatment) tertentu dalam kondisi yang dikendalikan (Sugiyono, 2016). Metode eksperimen yang digunakan adalah dalam bentuk Single Subject Research (SSR). Subjek tunggal digunakan untuk menyelidiki perubahan tingkah laku seseorang yang timbul akibat beberapa perlakuan dan dipakai jika sampel satu (Sunanto, 2005). Adapun desain yang dipakai untuk penelitian SSR ini menggunakan desain A-B-A', dengan keterangan A yaitu kondisi saat baseline-1, dan $\mathrm{B}$ adalah kondisi saat pemberian perlakuan (intervensi) serta $A^{\prime}$ adalah kondisi setelah perlakuan atau baseline-2 (A'). Penggunaan desain A-B-A' yaitu untuk mengetahui perbandingan kondisi siswa saat baseline sebelum diberikan intervensi, saat intervensi ketika berupa perlakuan, serta pada saat baseline-2 setelah intervensi ditarik.

Dalam peneltian ini terdapat 2 variabel yaitu variabel bebas dan variabel terikat. Menurut Widoyoko, (2012). "Variabel bebas adalah variabel yang mempengaruhi variabel lain yaitu variabel terikat. Pada penelitian ini variabel bebas adalah intervensi atau perlakuan berupa media papan balik dan variabel terikatnya adalah target behavior yaitu membaca permulaan.

Siswa autis kelas 1 berjenis kelamin laki-laki merupakan subjek tunggal dalam penelitian ini yang berumur 10 tahun dan bersekolah di SLB Autis Laboratorium Universitas Negeri Malang. Instrumen dalam penelitin ini menggunakan jenis instrumen observasi, validasi para ahli, serta instrumen butir soal dengan bentuk cheklis. Analisis data dilakukan untuk mengetahui efek dari pemberian intervensi yang diberikan, serta menjelaskan gambaran pelaksanaan eksperimen sebelum dan sesudah diberikan intervensi. Analisis data yang digunakan dalam penelitian ini adalah teknik statistik deskriptif.

Statistik deskriptif yaitu berupa analisis visual terdiri atas analisis dalam kondisi dan analisis antar kondisi karena penelitian menggunakan subjek tunggal sehingga data terfokus pada individu. Hasil data penelitian yang diperoleh setelah diolah dan dihitung dipaparkan dalam grafik yaitu untuk mengetahui pengaruh pemberian intervensi terhadap variabel terikat. Grafik tersebut memiliki peranan yang penting saat analisis data. Grafik menunjukkan penyajian data secara menyeluruh serta menjabarkan hasil analisa. Penelitian ini menggunakan grafik garis dalam penyajian data yang disajikan secara kontinyu sehingga menunjukkan grafik garis secara jelas perkembangan perubahan yang terjadi. 
Tabel 1. Hasil Rekapitulasi Data Kemampuan Membaca Permulaan Siswa Autis dari kondisi baseline-1 (A1), intervensi-1 (B), baseline-2 (A2) dan baseline-2 (B2)

\begin{tabular}{ll}
\hline Sesi & Nilai $(\mathbf{\%})$ \\
\hline 1 & 41.1 \\
2 & 40.5 \\
3 & 44.8 \\
4 & 46 \\
\hline 5 & 74.5 \\
6 & 71.8 \\
7 & 78.4 \\
8 & 78.4 \\
9 & 82.3 \\
\hline 10 & 64.8 \\
11 & 66.5 \\
12 & 72.6 \\
13 & 72.6 \\
\hline
\end{tabular}

Grafik 1. Hasil Rekapitulasi Data Kemampuan Membaca Permulaan Siswa Autis dari kondisi baseline-1 (A1), intervensi-1 (B), baseline-2 (A2) dan baseline-2 (B2)

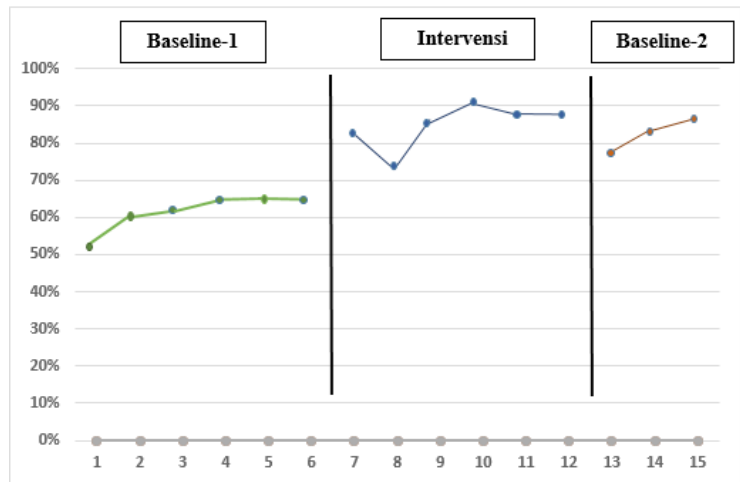

HASIL DAN PEMBAHASAN

Hasil

Penelitian ini dilaksanakan selama 13 kali pertemuan yaitu pada tanggal 11 maret sampai 9 april 2019. Pengumpulan data pada setiap kondisi yaitu baseline-1 (A1) sebanyak 4 kali, dan kondisi intervensi (B) 5 kali pertemuan, serta kondisi baseline-2 (A2) dilaksanakan sebanyak 4 kali. Target penelitian yang dinilai terdapat 5 aspek yaitu menyebutkan nama gambar, menyebutkan kata sederhana, menyebutkan huruf dan suku kata, merangkai suku kata menjadi kata, serta mencocokkan kata dengan gambar. Data hasil analisis yang didapat pada baseline (A1) yang merupakan kondisi awal sebelum diberikan perlakuan. Pada tahap ini peneliti memberikan tes 11 kata disertai dengan gambar sub tema merawat tubuh, saat kondisi intervensi subjek diberi perlakuan berupa menyebutkan nama gambar, menyebutkan kata sederhana, menyebutkan huruf dan suku kata, merangkai suku kata menjadi kata, serta mencocokkan kata dengan gambar, dan pada kondisi baseline-2 (A2) yaitu berupa pengulangan kondisi baseline untuk mengetahui tingkat pemberian intervensi berpengaruh terhadap kemampuan membaca permulaan siswa autis dengan membandingkan hasil pada baseline-1. Adapun data yang diperoleh dari penilaian indikator yang terdapat dalam lembar observasi dirubah diubah dalam bentuk persentase. Skor yang didapatkan oleh siswa pada tiap indikator kemudian dijumlah skor totalnya, hasil skor tersebut dibagi dengan skor maksimal dari seluruh indikator setelah itu dikalikan $100 \%$. Hasil persentase tersebut dianalisis menggunakan analisis grafik (visual analysis of graphic data). Dari hasil penelitian yang dilakukan didapatkan hasil penelitian dalam bentuk pesentase pada kondisi baseline 1 (A1), Intervensi 1 (B1), baseline 2 (A2), dan intervensi 2 (B2) dalam kemampuan membca permulaan seperti disajikan pada tabel 1. Secara Visual dapat dilihat dalam grafik 1.

Grafik tersebut menggambarkan perolehan data hasil penelitian membaca permulaan siswa autis kelas 1 dari baseline-1 (A1), kondisi intervensi (B), serta baseline-2 (A2) yang semuanya dijelaskan dalam garis berwarna biru dengan perolehan data seperti yang terlihat pada tabel 1. Saat kondisi baseline -1 (A1) sebesar 41,1\%-46\%, kondisi intervensi nilai terendah $71,8 \%$ dan nilai tertinggi $82,3 \%$, dan pada kondisi baseline-2 (A2) memperoleh nilai terendah $64,8 \%$ dan nilai tertinggi $72,6 \%$ yang terlihat pada tabel 1 saat kondisi baseline-1 (A1) menuju intervensi (B) dimana data memperoleh kenaikan sebesar 30,7\% dari 41,1\% ke 71,8\% dan pada kondisi intervensi (B) ke kondisi baseline-2 (A2) mengalami penurunan sebesar 9,7\% dari $82,3 \%$ menjadi $72,6 \%$. Data tersebut dianalisis menggunakan data dalam kondisi dan antar kondisi. Seperti yang disajikan dalam tabel 2. Pada penelitian ini (a) panjang kondisi dilaksanakan sebanyak 4 sesi pada tahap baseline 1 (A1), 5 sesi di tahap intervensi, serta 4 sesi ketika tahap baseline-2 (A2), (b) Garis estimasi cenderung kearah meningkat yang terlihat saat kondisi baseline-1 (A1) dengan simbol (+), (c) kecenderungan stabilitas saat baseline 1 (A1) adalah $100 \%$ yang berarti stabil, kecenderungan stabilitas kondisi intervensi (B) juga 100\%, serta pada kondisi baseline-2 (A2) kecenderungan stabilitas cenderung $100 \%$, (d) Berdasarkan garis jejak data, didapatkan bahwa saat baseline-1 (A1) jejak datanya juga meningkat, kemampuan membaca awal meningkat, pada kondisi intervensi (B) jejak data mengalami peningkatan yang artinya kemampuan membaca meningkat akibat perlakuan dan garis jejak . 
Tabel 2 Hasil Analisis Visual dalam Kondisi Membaca Permulaan Siswa Autis

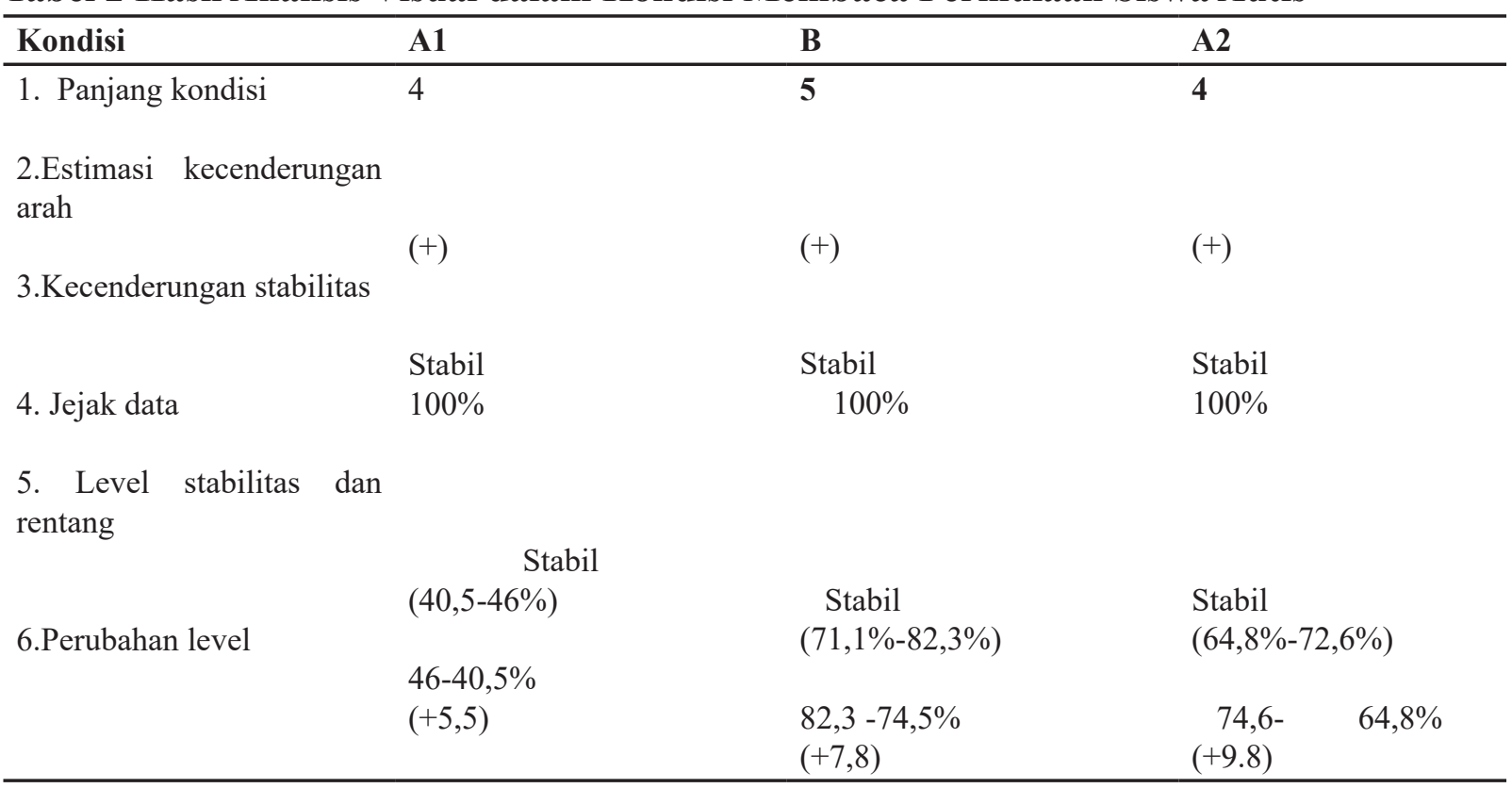

Tabel 3. Hasil Analisis Visua Antar Kondisi

\begin{tabular}{|c|c|c|c|c|c|}
\hline Perbandingan Kondisi & $\mathrm{B} / \mathrm{A}$ & & A2/B & & \\
\hline 1. Jumlah variabel & $\begin{array}{l}1 \\
(28,5 \%)\end{array}$ & & $\begin{array}{l}1 \\
(1,9 \%)\end{array}$ & & \\
\hline $\begin{array}{l}\text { 2.Perubahan kecender } \\
\text { efeknya }\end{array}$ & $(+)$ & $(+)$ & & $(+)$ & $(+)$ \\
\hline 3.Perubahan kecenderu & Stabil ke stabil & & Stabil ke stabil & & \\
\hline 4. Perubahan level & $\frac{74,5 \%-46 \%}{(28,5 \%)}$ & & $\frac{74,5 \%-72.6 \%}{(1,9 \%)}$ & & \\
\hline 5.Persentas overlap & $0 \%$ & & - & & \\
\hline
\end{tabular}

Pada kondisi baseline-2 (A2) yaitu meningkat yang menggambarkan terdapat dampak yang positif pada kondisi intervensi, (e) Pemerolehan data saat baseline (A1) cenderung meningkat dalam rentang $41,1 \%-46 \%$, dan pada kondisi meningkat (A2) cenderung meningkat dan stabil dengan rentang $71,8 \%-82,3 \%$, dan kondisi baseline-2 (A2) dengan rentang 64,8\%-72,6\%, (f) saat kondisi baseline 1 (A1) menggambarkan tanda $(+)$ yang artinya meningkat, intervensi (B) menunjukkan tanda $(+)$ yang berarti meningkat, dan baseline-2 (A2) menunjukkan tanda (+) yang berarti meningkat dan terdapat perubahan setelah intervensi dihentikan.

Data tersebut juga dianalisis dalam kondisi yaitu : (a). Variabel yang diubah yaitu berjumlah satu yaitu kondisi baseline ke intervensi, (b) Kecenderungan arah yang diperoleh dari kondisi baseline-1 (A1) ke intervensi (B) yaitu meningkat, yang berarti kondisi tersebut meningkat karena perlakuan, dan pada kondisi intervensi ke baseline-2 adalah dari meningkat ke meningkat yang artinya pemberian perlakuan meningkatkan kemampuan membaca permulan siswa autis kelas 1, (c). Perubahan kecenderungan stabilitas dari baseline-1 ke intervensi adalah stabil menuju stabil dan intervensi ke baseline-2 adalah stabil ke stabil, (d) kemampuan membaca siswa autis dari baseline-1 menuju intervensi yaitu mengalami peningkatan sebesar $28,5 \%$ dan saat kondisi intervensi ke baseline-2 juga mendapat peningkatan yaitu sebesar $1,9 \%$, (e) Persentase Overlape atau data yang tumpang tindih dari kondisi baseline-1 ke iintervensi adalah $0 \%$ dan persentase overlape intervensi ke baseline-2 tidak perlu dihitung dikarenakan baseline- 2 berperan sebagai kontrol. Persentase overlape sebesar $0 \%$ menunjukkan bahwa pemberian intervensi berupa media papan balik memberikan pengaruh terhadap kemampuan membaca permulaan siswa autis yang disajikan dalam tabel 2 . 
Berdasarkan pemerolehan analisis data, baik itu analisis dalam kondisi maupun analisis antar kondisi memaparkan bahwa estimasi kecenderungan arah, kecenderungan kestabilan, jejak data serta perubahan tingkat kemampuan membaca permulaan siswa autis yang meningkat. Sehingga dapat ditarik kesimpulan bahwa kemampuan membaca permulaan siswa autis dapat dioptimalkan melalui penggunaan media papan balik.

\section{Pembahasan}

Berdasarkan penelitian yang telah dilakukan dengan kondisi baseline-1 (A1) sebanyak 4 sesi, kondisi intervensi (B) sebanyak 5 sesi dan, kondisi baseline-2 (A2) sebanyak 4 sesi. Peneliti memberikan tes 11 kata dengan sub tema merawat tubuh yang dilaksanakan oleh subjek meliputi menyebutkan nama gambar, menyebutkan kata sederhana, menyebutkan huruf dan suku kata, merangkai suku kata menjadi kata, serta mencocokkan kata dengan gambar.

Membaca adalah bagian dari aspek keterampilan berbahasa yang harus dikuasai sebagai prasyarat belajar mata pelajaran selanjutya. " reading is defined as that part of the language art developmental sequence is listening, speaking, reading and writing which requiring the comprehension of written verbal symbol" Hargrove dan James (1984). Pada tahap membaca permulaan yaitu meliputi kegiatan mengenal abjad, suku kata, kata maupun kalimat. Kemampuan membaca permulaan yaitu sebagai dasar bagi kemampuan membaca selanjutnya dan apabila dasar tersebut tidak kuat, maka akan berpengaruh pada fase membaca berikutnya (Nafiah, 2016).

Saat observasi dilakukan kemampuan membaca subjek masih cukup rendah terutama dalam membaca suku kata ke kata selain itu intonasi yang diucapkan masih kurang jelas. Salah satu faktor penghambat siswa dalam membaca permulaan adalah kesulitan dalam membuat kontak mata sehingga menghambat kemampuannya dalam belajar.

Siswa autis mengalami kesulitan untuk menafsirkan informasi dalam ekspresi wajah dan kontak mata yang mempengaruhi kemampuannya dalam berinteraksi dengan orang lain (Winczura, 2014). Sejalan dengan pendapat tersebut Salim (2007) mengatakan" Kontak mata merupakan kemampuan untuk melakukan hubungan timbal balik sebagai awal terjadiya interaksi sosial melalui tatap muka atau mata secara langsung. Berdasarkan hal tersebut dibutuhkan sebuah media yang dapat menarik minat siswa untuk belajar sesuai dengan karakteristik gaya belajarnya.

Pada penelitian ini kondisi baseline dilaksanakan sebanyak dua kali baseline, yaitu kondisi baseline-1 (A1) berjumlah 4 sesi dan baseline-2 (B2) dengan berjumlah 4 sesi. Kondisi tersebut digunakan untuk mengetahui kemampuan subjek dengan diberikan tes tanpa sebuah perlakuan (intervensi). Perolehan data kemampuan membaca permulaan siswa saat kondisi baseline-1 (A1) masih rendah yaitu pada rentang 40,5\%-46\% menunjukkan bahwa perubahan nilainya masih sedikit, hal tersebut dikarenakan saat baseline-1 bertujuan untuk mengetahui kemampuan membaca awal subjek yaitu siswa autis. Setelah dilakukan fase baseline 1 (A1) yang menunjukkan hasil yang rendah dan telah stabil maka dibutuhkan sebuah perlakuan atau intervensi untuk meningkatkan hasil skor yang rendah tersebut.

Pada kondisi baseline-2 (A2) menunjukkan bahwa skor yang diperoleh lebih tinggi dari pada saat kondisi baseline-1(A1), Sehingga dapat diketahui bahwa terdapat peningkatan kerena kontrol yang diberikan berupa perlakuan (intervensi). Pada kondisi baseline-2 (A2) yang dilakukan setelah kondisi intervensi menunjukkan pemerolehan skor yang menurun dari hasil intervensi pada sesi pertama namun sesi selanjutnya mengalami peningkatan, dan bila dibandingkan dengan baseline-1 (A1) mengalami peningkatan yang cukup signifikan dengan rentang antara $64.8 \%-72.6 \%$.

Peningkatan tersebut disebabkan oleh adanya perlakuan atau intervensi yaitu berupa penggunaan media papan balik yang merupakan modifikasi dari flipchart. Menurut Pratiwi (2013) menjelaskan bahwa media papan balik (flipchart) adalah lembaran yang dijilid menjadi satu berisi gambar, huruf, diagram maupun angka. Namun papan balik dalam penelitian ini adalah papan balik yang sudah dimodifikasi dalam bentuk papan yang terbuat dari kayu triplek tebal dan dapat dibalik berisi gambar, angka serta kartu huruf yang bisa diganti sesuai dengan tema pembelajaran. Pemodfikasian flipchart ini didasarkan oleh bentuk flipchart yag relatif kecil, terbatas dengan tema dan, Kurang sesuai untuk pembelajaran klasikal dalam skala besar.

Pengaruh penggunaan media papan balik dalam meningkatkan kemampuan membaca permulaan siswa autis kelas 1 di SLB Autis Laboraturium Universitas Negeri Malang dapat dilihat dari hasil analisis data antar kondisi menunjukan adanya peningkatan dalam kemampuan membaca permulaan, yang ditunjukkan dengan kecenderungan arah dan efeknya yang meningkat dari kondisi baseline-1(A1) ke kondisi baseline-2(A2). Perolehan skor kemampuan membaca permulaan pada baseline-1(A1) berkisar antara $40,5 \%-46 \%$. Sementara itu, peningkatan skor yang cukup signifikan ditunjukkan selama kondisi intervensi (B) yaitu 71,8\%-82,3\%, kemudian untuk fase kontrol baseline-2(A2) skor kemampuan membaca permulaan yaitu 64.8\%-72.6\%. Perubahan level antara sesi terakhir fase baseline 1(A1) dan pada sesi pertama intervensi (B) terdapat selisih sebesar $(+28,5 \%)$ yang merupakan peningkatan kemampuan membaca permulaan sebelum diberikan intervensi dan saat intervensi. 
Berdasarkan hasil dari analisis data yang disajikan dalam bentuk grafik garis dengan menggunakan desain A-B-A, dapat dikatakan bahwa media papan balik memiliki pengaruh terhadap kemampuan membaca permulaan siswa autis. Hal tersebut dapat ditunjukkan dari persentase data overlap antara fase baseline satu ke fase intervensi yakni $0 \%$. Sunanto (2005) menyatakan bahwa semakin kecil data overlape semakin baik pengaruh intervensi pada target behavior. Sehingga dapat ditarik sebuah kesimpulan yaitu pemberian intervensi (B) dalam penelitian ini papan balik berpengaruh terhadap kemampuan membaca permulaan autis.

\section{KESIMPULAN DAN SARAN}

\section{Kesimpulan}

Berdasarkan dari hasil pembahasan dan analisa data, maka dapat ditarik kesimpulan antara lain: (1) kemampuan membaca permulaan siswa autis lebih rendah sebelum diberikan intervensi, dimana subjek masih kesulitan dalam membaca kata, suku kata, maupun dalam menyamakan kata dengan gambar (2). Kemampuan membaca siswa autis meningkat setelah diberikan intervensi berupa media papan balik. Peningkatan tersebut terlihat dari skor yang diperoleh siswa saat intervensi maupun setelah intervensi ditarik, (3). Media papan balik berpengaruh terhadap kemampuan membaca permulaan. Pengaruh penggunaan media papan balik terlhat dari level perubahan pada baseline-1 sampai baseline-2 serta terlihat dari data overlape yang menunjukkan tidak terdapat kesenjangan pada data intervensi ke baseline yaitu $0 \%$ sehingga disimpulkan bahwa pemberian intervensi berpengaruh terhadap target behavior.

\section{Saran}

Berdasarkan hasil penelitian mengenai pengaruh media papan balik terhadap kemampuan membaca permulaan siswa autis kelas 1 di SLB Autis Laboratorium Universitas Negeri Malang terdapat saran yang penulis tujukan yaitu: (1) Guru kelas hendaknya dalam proses kegiatan pembelajaran agar guru menggunakan media Papan Balik dalam kegiatan belajar membaca permulaan supaya hasil belajar siswa mengalami peningkatan, (2) Peneliti selanjutnya yaitu diharapkan dapat mengembangkan media pembelajaran semenarik mungkin sehingga dapat meningkatkatkan minat siswa untuk belajar, tidak hanya dalam aspek membaca. Hal tersebut bertujuan untuk memberikan pelayan yang optimal sesuai dengan karakteristik anak berkebutuhan khusus.

\section{DAFTAR PUSTAKA}

Ayu, Q. R., \& Sudarsini, S, (2018)” Metode syllabic untuk meningkatkan keterampilan membaca permulaan anak autis. Jurnal ortopedagogia, 2(1), 21-25

Hargrove, L. \& James, A. (1984) Assessment in Special Education: The Education Evaluation. Prentice Hall.

Kamus Besar Bahasa Indonesia (KBBI). Pengertian Papan dan Balik. Online.

Diakses 23 februari 2019.

Koswara, D (2013). Pendidikan Anak Berkebutuhan Khusus Autis. Jakarta; PT Luxima Metro Media.

Kustiawan, U. (2018). Sumber Dan Media Pembelajaran Anak Usia Dini. Karya Dosen Fakultas Ilmu Pendidikan UM.

Mundy, P \& Mastergeorge, A. M. (2012). Educational Intervention for Student With Autism.

Nafiah, A. C. (2016). Peningkatan kemampuan membaca permulaan melalui metode scramble membaca kalimat siswa kelas II SDN Sedayu. Basic Education, 5(24), 2-289.

Pratiwi, D. E. (2013). Penerapan Media Papan Balik (Flipchart) Pada Pembelajaran Temtik Untuk Meningkatkan Hasil Belajar Siswa Sekolah dasar. ."Jurnal Penelitian Pendidikan Guru Sekolah Dasar, 1(2), 1-10

Salim, D (2007). Matinya Mozart Effect. Yogyakarta: Galanggangpress.

Sugiyono, (2016). Metode Penelitian Kuantitatif, Kualitatif, dan $R \& D$. Bandung. Alfabeta

Sunanto, J., Takeuchi, K., \& Nakata, H. (2005). Pengantar Penelitian dengan Subjek Tunggal. Japan: University Of Tsukuba.

Tarigan, H.G. (2008). Membaca sebagai suatu keterampilan berbahasa. Bandung. Angkasa

Universitas Negeri Malang. (2010). Pedoman Penulisan Karya Ilmiah. Malang: Universitas Negeri Malang

Wahyudin, E. Pengaruh Media Flipchart Terhadap Kemampuan Membaca Anak Usia Dini Kelompok B TK Negeri Pembina Ciawigebang. Jurnal PAUD Agapedia, 1(2), 137-143

Widoyoko, E,P. (2012). Teknik Penyusunan Instrumen Penelitian. Yogyakarta. Pustaka Pelajar, 15, 22

Winczura, B. (2014). Deficiencies of Eye Contact and Face-to-Face Interactions in Social Relations Among Children with Autism. Pedagogy Studies/ Pedagogika, 116(4). 